\title{
Genetic Relationship Among Leptogenys Chinensis and Myrmicaria Brunnea (Hymenoptera: Formicidae) by RAPD Molecular Markers
}

\author{
Barsagade D. D., Nagarkar D. A., Masram P. P., Thakre M. P.
}

\section{ABSTRACT}

\begin{abstract}
Ants are important factor in ecosystem. They are greatly affected with environmental changes and human interference. Ants biomass do not look a lot like species richness and so their genetic information is valuable. Myrmicaria brunnea, harvester ant and Leptogenys chinensis, long legged ant used in study as representatives of Myrmicinae and Ponerinae respectively. RAPD technique is most common, reliable and cost-effective for study of genetic variability among different species. DNA marker was used for assessment of genetic integrity and variation among Myrmicaria brunnae and Leptogenys chinensis. Three RAPD markers, as P1, P2 and $P 3$ generated 151 bands. M. brunnae and $L$. chinensis generated 66 and 85 bands respectively. Maximum polymorphic bands were generated by $\mathbf{P 2}$ primer (37) while, maximum monomorphic (17) bands were generated by primer P1. Study of monomorphic and polymorphic bands were carried out and statistical data generated were used to construct phylogenetic tree and fluorograms. $M$. brunnae and $L$. chinensis were found linked together at about 0.4 genetic distance.
\end{abstract}

Keywords: Ants, Myrmicaria, Leptogenys, RAPD, PCR, Hymenoptera.

\section{INTRODUCTION}

In ecosystem, ants are of great significance due to their biomass and work for maintaining health and stability of the environment. Ants act as pollinators, seed dispersers and are important to nutrient cycling and ecosystem functioning. [7] [18]

Among 660 species from 87 genera of ants, Myrmicaria family has maximum diversity i.e. $45 \%$ of total Indian ants [18]. Ponerinae is largest subfamily of poneromorphs, 23 genera of ponerini found on all continents and major islands [4] [15] while, subfamily ponerinae with $14 \%$ diversity of species among which Leptogenys shows maximum diversity [8] still least studied. From a common evolutionary ancestral group poneromorphs suggested to be descended, diverged early on, near base of formicide tree [19].

In taxonomy, precise anatomical differences are used for classifying closely related species. In case of ants, it requires lots of taxonomic knowledge. Morphological data [6] and molecular data [3] [21] [27] [28], gives undisputable support for monophyletic origin of ants [18].
Published Online: August 2, 2020

ISSN: $2684-5199$

DOI : 10.24018/ejbio.2020.1.4.62

Barsagade D. D.

Department of Zoology, MJF Educational campus, RTM Nagpur University, India.

Nagarkar D. A.*

New English Junior College, Mahal, India. (e-mail: dewashreenagarkar@gmail.com)

\section{Masram P. P.}

Elphistone College, India.

Thakre M. P.

Dept. Of Zoology, KZS Science College, Bramhani- Kalmeshwar, Dist: Nagpur, India.

*Corresponding

dewashreenagarkar@gmail.com
Environmental changes, vehicular vibration and additional manuring affects ant's population. Extinction is a demographic process that is likely to be influence of genetic factors [1]. Among social hymenopterans, though ants share common character like social behaviour and haploid male but differ in perennial and iteroparous colonies. Perennial species react more slowly to changing environment. Ants are omnipresent but their quantity (biomass) does not correspond to species richness. Wilson [29], Holldobler and Wilson [15] propose that more than one third of ant biodiversity still undiscovered and may go extinct before being discovered and studied [22].

Myrmicaria commonly known harvester ant and Leptogenys commonly known as long legged ants having rare ecological status [16]. For nesting Myrmicaria and Leptogenys prefers tree base and logs respectively. Leptogenys chinensis and Myrmicaria brunnea are major predators of Antheraea mylitta and affects tasar silk production [10]. Leptogenys khammouanesis newly identified species collected from cave shown characters like reduced eyes, light pigmentation, slender body, very elongated legs and antennae [20]. 
Recent years modern techniques in molecular biology such as polymerase chain reaction (PCR) and automated DNA sequencing greatly used in biology [14] for assessment of genetic variability. RAPD or Random Amplified Polymorphic DNAs technique is most common, reliable and cost- effective. DNA markers on PCR amplification detects small inverted repeats scattered throughout the genome helps in analysis of relatedness between genotype [12].

Diagnostic molecular characters can be generated with different primers, for taxonomic levels. In systematic relationships, constant fragments may be diagnostic for any one operational taxonomic units (OTU) and polymorphic for between OTUs [12].

Present study aims to examine genetic integrity and variation of Leptogenys chinensis and Myrmicaria brunnae assessed by RAPD markers using Fluorescent labelled primers.

\section{MATERIAL AND METHOD}

\section{A. Sample collection}

Leptogenys chinensis and Myrmicaria brunnae collected from Rashtrasant Tukdoji Maharaj, Nagpur University educational campus, Nagpur, Maharashtra state of India. The ants were collected by brush and transferred to collection tube containing $100 \%$ alcohol. The samples were coded Leptogenys chinensis (L1) as S1 and Myrmicaria brunnae (M2) as S2.

\section{B. Extraction of genomic DNA}

Genomic DNA was isolated from both samples using Chromus Genomic DNA isolation kit (RKN80/81). Samples homogenized with $200 \mu \mathrm{l}$ C-TAB isolation buffer on cooling added $10 \mu \mathrm{l}$ of RNase A solution. Samples firstly incubated at $37^{0} \mathrm{C}$ for 15 minutes and then for 30 minutes at $65^{\circ} \mathrm{C} .1 \mathrm{ml}$ of Chloroform: isoamylalcohol (24:1) mix added on cooling and centrifuged at 10000rpm for 10 minutes, in supernatant equal volume of Phenol: (Chloroform: Isoamyl alcohol) 1:1 added and centrifuged at $10000 \mathrm{rpm}$ for 10 minutes. Precipitation solution (1:1 ratio) added in supernatant. White strands of genomic DNA separated were incubated at $-20^{\circ} \mathrm{C}$ for 30 minutes.

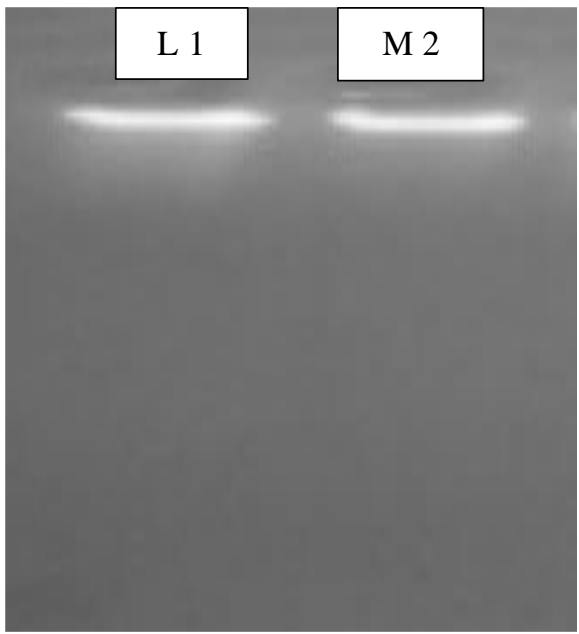

Fig. 1 Genomic DNA extracted from L1 L. chinensis and M2 M. brunnae loaded on $1 \%$ agarose gel.

\section{RAPD primers screening}

Genomic DNA was taken up for PCR amplification using 06 different randomly selected fluorescent labelled 20-mer RAPD primers (Chromous Biotech Pvt. Ltd., India). Primers that gave clear profiles were chosen for further study. Details of RAPD primers and their sequences are given in Table 1.

TABLE 1: Sequence, code and nucleotide length of primers used for RAPD analysis

\begin{tabular}{|l|l|l|l|}
\hline $\begin{array}{l}\text { S. } \\
\text { N } \\
.\end{array}$ & $\begin{array}{l}\text { Primer sequence } \\
\left(5^{\prime} \rightarrow 3^{\prime}\right)\end{array}$ & $\begin{array}{l}\text { Primer } \\
\text { code }\end{array}$ & $\begin{array}{l}\text { Nucleoti } \\
\text { de length }\end{array}$ \\
\hline 1 & -CCCHGCAMCTGMTCGCACHC- & P1 & 20 -mers \\
\hline 2 & -AGGHCTCGATAHCMGVY- & P2 & 17 -mers \\
\hline 3 & -MTGTAMGCTCCTGGGGATTCHC- & P3 & 22-mers \\
\hline
\end{tabular}

\section{PCR Amplification}

Reaction mixture $(25 \mu \mathrm{l})$ containing 10X Chrom Taq Assay buffer $(2.5 \mu \mathrm{l})$, 50ng of genomic DNA $(0.5 \mu \mathrm{l}), 100 \mathrm{ng} / \mu \mathrm{l}$ RAPD primer $(2.0 \mu \mathrm{l}), 10 \mathrm{mM}$ dNTPs $(1.0$ $\mu \mathrm{l})$, Chrom-Taq DNA polymerase $(3 \mathrm{U} / \mu \mathrm{l})(0.5 \mu \mathrm{l})$ and $18.5 \mu \mathrm{l}$ of sterile distilled water incubated in ABI Thermal cycler:2720 DNA engine thermal cycler programmed for 40 cycles, denaturation at $94{ }^{\circ} \mathrm{C}$ for 5 minutes, annealing at $55^{\circ} \mathrm{C}$ for 1 minute and 2 minutes for elongation at $72^{\circ} \mathrm{C}$.

Amplification product were electrophoresed on $2 \%$ agarose gel in $1 \mathrm{X}$ TAE buffer mixed with $5 \mu \mathrm{l}$ of staining dye at $100 \mathrm{~V}$ and then photographed. Two molecular weight markers 500bp DNA ladder and 100bp DNA ladder were used for assessment.

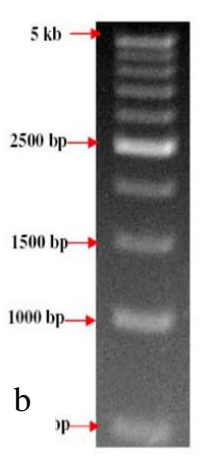

a

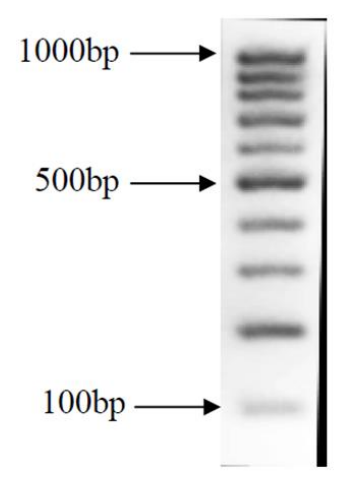

b
Fig. 2: (a) 500bp ladder contains 10 DNA fragments of size $500 \mathrm{bp}, 1000 \mathrm{bp}$, $1500 \mathrm{bp}, 2000 \mathrm{bp}, 2500 \mathrm{bp}, 3000 \mathrm{bp}, 3500 \mathrm{bp}, 4000 \mathrm{bp}, 4500 \mathrm{bp}$ and $5000 \mathrm{bp}$. (b) $100 \mathrm{bp}$ DNA ladder contains 10 DNA fragments of size 100bp, 200bp, 300bp, 400bp, 500bp(spiked), 600bp,700bp, 800bp, 900bp and $1 \mathrm{~kb}$.

\section{E. Statistical Analysis}

Analysis of the molecular data for $L$. chinensis and $M$. brunnae scored on the basis of clear genomic DNA bands 1 for presence of a band and 0 for absence of band. If amplified product was absent in any one of the samples used for analysis, counted as polymorphic, and considered monomorphic if the amplified product was present in both samples.

The binary data from the fluorescent labelled RAPD primers by gene mapper (ABI Genetic Analyser; 3500xL) produced the RAPD profiles, data was subjected to Neighbor- 
joining cluster analysis using Free Tree and Tree View software for phylogenetic analysis.

Coefficient of simple coincidence $\left(S_{i j}\right)$, in which the genetic similarity between the $\mathrm{i}^{\text {th }}$ and $\mathrm{j}^{\text {th }}$ individual calculated by:

Where,

$$
\mathrm{S}_{\mathrm{ij}}=\mathrm{a}+\mathrm{d} / \mathrm{a}+\mathrm{b}+\mathrm{c}+\mathrm{d}
$$

$\mathrm{a}=$ number of bands present in both sample $(1,1)$

$\mathrm{b}=$ number of bands present in first sample and absent in second sample $(1,0)$

$\mathrm{c}=$ number of bands in absent first sample and present in second sample $(0,1)$

$\mathrm{d}=$ absence of bands in both samples $(0,0)$

for coefficient of similarity we considered double absence i.e d. absence of bands as evidence of homology (Skorch et al. 1992, Waldschmidt et al. 2002). The genetic similarity converted to genetic distance using expression:

$\mathrm{Dij}=1-\mathrm{Sij}$

Similarity index was used to calculate the genetic distance values and to construct the phylogenetic tree/ dendrogram.

\section{RESULTS:}

\section{A. RAPD profiles}

Isolated DNA from L. chinensis and M. brunnae were used to produce RAPD-based DNA profiles. Three random primers were applied for RAPD amplification.

TABLE 2: Bands obtained in sample 1 (L. chinensis) and sample 2 ( $M$. brunnae) with three random primers

\begin{tabular}{|c|c|c|c|}
\hline \multirow{2}{*}{ Sr.No. } & \multirow{2}{*}{ Primer code } & \multicolumn{2}{|c|}{ Bands Obtain } \\
\cline { 3 - 4 } & & Sample 1 & Sample 2 \\
\hline 1 & P1 & 34 & 34 \\
\hline 2 & P2 & 26 & 37 \\
\hline 3 & P3 & 6 & 14 \\
\hline
\end{tabular}

Total bands generated by sample 1 (L. chinensis) were 66 and sample 2 ( $M$. brunnae) were 85 . The number of bands generated by individual primers shown in Table 2, Fig. 3.

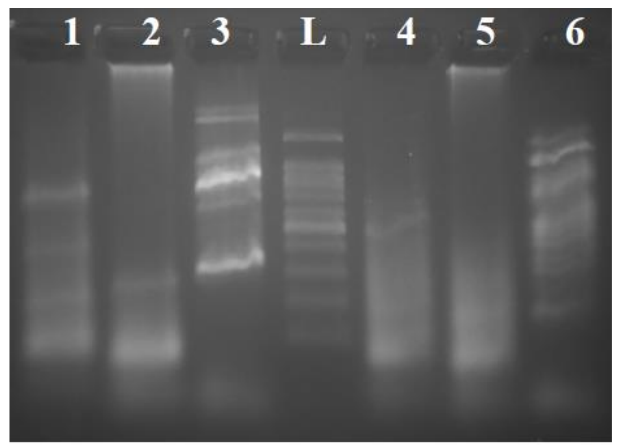

Fig. 3: Banding patterns of RAPD fragments of sample 1 (L. chinensis) and sample 2 (M. brunnae) with primer P1, P2, P3. Lane 1 is sample $1 \mathrm{v} / \mathrm{s} \mathrm{P1,}$ Lane 2 is sample $1 \mathrm{v} / \mathrm{s} \mathrm{P} 2$, Lane 3 is sample $1 \mathrm{v} / \mathrm{s} \mathrm{P} 3$, Lane L is a marker $100 \mathrm{bp}$ ladder, Lane 4 is sample $2 \mathrm{v} / \mathrm{s} \mathrm{P} 1$, Lane 5 is sample $2 \mathrm{v} / \mathrm{s} \mathrm{P} 2$, Lane 6 is sample $2 \mathrm{v} / \mathrm{s} \mathrm{P} 3$.

\section{B. Level of Polymorphism}

\section{Banding pattern:}

RAPD profiles obtained through amplification of genomic DNA of $L$. chinensis and $M$. brunnae showed different primers generated monomorphic and polymorphic bands. Compare to L. chinensis and M. brunnae primers generated 151 fragment bands. Percentage of polymorphic bands and monomorphic bands produced by 3 primers shown in Table 3 and 4. Furthermore, polymorphic bands produced by RAPD analysis in $L$. chinensis and $M$. brunnae with percentage of polymorphic bands using 3 primers shown in Table 5 and 6 . The results showed different primers produced different fragment pattern i.e. different number and different DNA length (Fig.6-11).

TABLE 3: Polymorphic bands between L. chinensis and M. brunnae by RAPD markers.

\begin{tabular}{|c|c|c|c|c|c|}
\hline $\begin{array}{c}\text { Sr. } \\
\text { No. }\end{array}$ & Primer & $\begin{array}{c}\text { Number } \\
\text { of } \\
\text { scorable } \\
\text { bands }\end{array}$ & $\begin{array}{c}\text { Molecular } \\
\text { size (bp) }\end{array}$ & $\begin{array}{c}\text { Number of } \\
\text { Polymorphic } \\
\text { bands }\end{array}$ & $\begin{array}{c}\% \\
\text { Polymorphic } \\
\text { band }\end{array}$ \\
\hline 1 & P1 & 51 & $50-326$ & 34 & 66.66 \\
\hline 2 & P2 & 40 & $50-326$ & 37 & 92.5 \\
\hline 3 & P3 & 18 & $52-500$ & 16 & 88.88 \\
\hline
\end{tabular}

TABLE 4: Monomorphic bands between L. chinensis and M. brunnae by

\begin{tabular}{|c|c|c|c|c|c|}
\hline $\begin{array}{c}\text { Sr. } \\
\text { No. }\end{array}$ & Primer & $\begin{array}{c}\text { Number } \\
\text { of } \\
\text { scorable } \\
\text { bands }\end{array}$ & $\begin{array}{c}\text { Molecular } \\
\text { size (bp) }\end{array}$ & $\begin{array}{c}\text { Number of } \\
\text { Monomorphic } \\
\text { bands }\end{array}$ & $\begin{array}{c}\% \\
\text { Monomorphic } \\
\text { band }\end{array}$ \\
\hline 1 & P1 & 51 & $52-161$ & 17 & 33.33 \\
\hline 2 & P2 & 40 & $51-302$ & 13 & 25.49 \\
\hline 3 & P3 & 18 & $267-271$ & 02 & 11.11 \\
\hline
\end{tabular}

TABLE 5: Polymorphic bands in L. chinensis.

\begin{tabular}{|c|c|c|c|c|c|}
\hline Sr. & Primer & $\begin{array}{c}\text { Tumber } \\
\text { of } \\
\text { bo. }\end{array}$ & $\begin{array}{c}\text { Molecular } \\
\text { size (bp) }\end{array}$ & $\begin{array}{c}\text { Number of } \\
\text { polymorphic } \\
\text { bands }\end{array}$ & $\begin{array}{c}\% \\
\text { Monomorphic } \\
\text { band }\end{array}$ \\
\hline 1 & P1 & 34 & $53-325$ & 17 & 50 \\
\hline 2 & P2 & 26 & $54-220$ & 13 & 50 \\
\hline 3 & P3 & 06 & $80-281$ & 04 & 66.66 \\
\hline
\end{tabular}

TABLE 6: Polymorphic bands in M. brunnae.

\begin{tabular}{|c|c|c|c|c|c|}
\hline $\begin{array}{c}\text { Sr. } \\
\text { No. }\end{array}$ & Primer & $\begin{array}{c}\text { Notal } \\
\text { of } \\
\text { bands }\end{array}$ & $\begin{array}{c}\text { Molecular } \\
\text { size (bp) }\end{array}$ & $\begin{array}{c}\text { Number of } \\
\text { polymorphic } \\
\text { bands }\end{array}$ & $\begin{array}{c}\% \\
\text { Monomorphic } \\
\text { band }\end{array}$ \\
\hline 1 & P1 & 34 & $59-326$ & 17 & 50 \\
\hline 2 & P2 & 37 & $50-326$ & 24 & 64.86 \\
\hline 3 & P3 & 14 & $53-500$ & 12 & 85.71 \\
\hline
\end{tabular}

2. Distance matrix table and Phylogenetic analysis:

Data from RAPD primers pooled together and genetic distance matrix was plotted using FreeTree and TreeView software Table 7, further subjected to Neighbor joining cluster analysis software and phylogenetic tree was constructed to evaluate the genetic diversity between $L$. chinensis and M. brunnae. The percent of polymorphism and genetic relationship among the both samples were analysed by developing phylogenetic tree Fig.4. Dendrogram cluster for L. chinensis and M. brunnae shown 2 clusters (Fig. 5) two samples were linked together with 100bootstrap. 
European Journal of Biology and Biotechnology www.ejbio.org

TABLE 7: Distance matrix of L. chinensis and M. brunnae showing the genetic variation revealed by fluorescent-labelled RAPD markers using

\begin{tabular}{|c|c|c|}
\hline \multicolumn{3}{|c|}{ Nei's genetic diversity. } \\
\hline & L. chinensis & M. brunnae \\
\hline L. chinensis & & 0.57616 \\
\hline M. brunnae & 0.57616 & \\
\hline
\end{tabular}

$$
\begin{aligned}
& \text { - } 100 \% \\
& \text { :... S1 } \\
& \begin{array}{ll}
1 \ldots & S 1 \\
\cdots & S 2
\end{array}
\end{aligned}
$$

Fig. 4: Reference tree

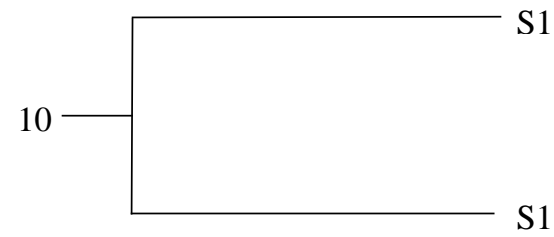

S1

Fig. 5: Dendrogram showing the clustering pattern between L. chinensis and $M$. brunnae revealed by FRAPD markers.

\section{Fluorograms:}

RAPD profiles of L. chinensis and M. brunnae with primer 1,2 and 3 displayed as fluorograms. Single peak corresponds to single band on the gel.

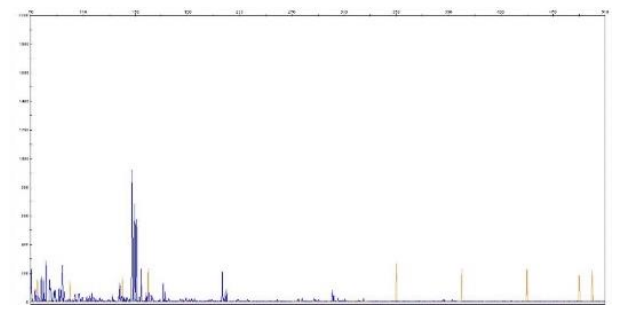

Fig. 6: Fluorogram of RAPD pattern of $L$. chinensis produced on the automated DNA sequencer (ABI genetic Analyser; 3500xL). Primer 1 was used for amplification reaction

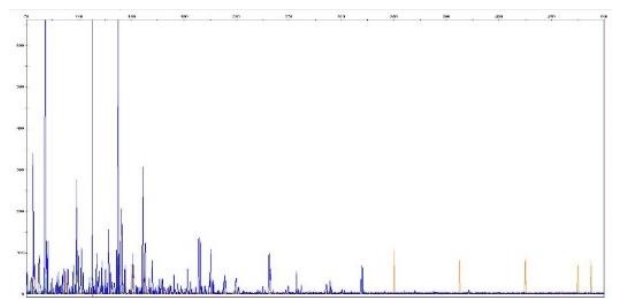

Fig. 7: Fluorogram of RAPD pattern of M. brunnae produced on the automated DNA sequencer (ABI genetic Analyser; 3500xL). Primer 1 was used for amplification reaction

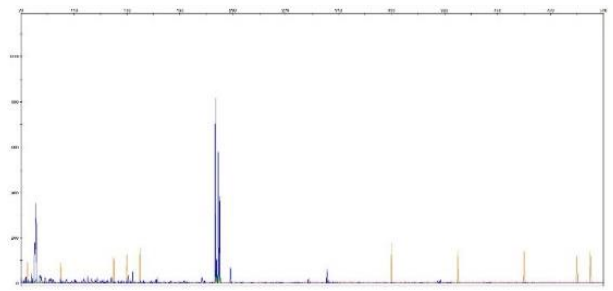

Fig. 8: Fluorogram of RAPD pattern of $L$. chinensis produced on the automated DNA sequencer (ABI genetic Analyser; 3500xL). Primer 2 was used for amplification reaction.

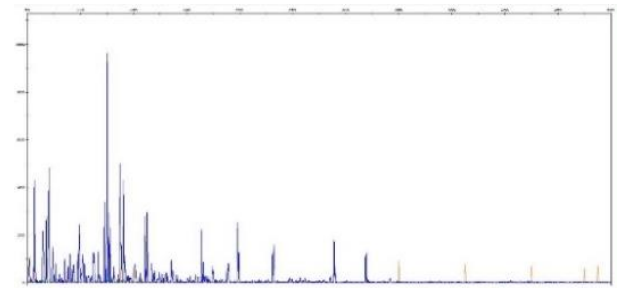

Fig. 9: Fluorogram of RAPD pattern of $M$. brunnae produced on the automated DNA sequencer (ABI genetic Analyser; 3500xL). Primer 2 was used for amplification reaction.

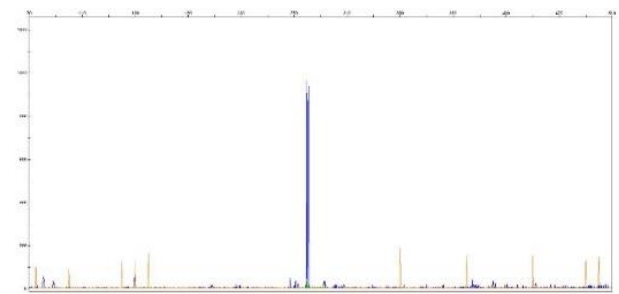

Fig. 10: Fluorogram of RAPD pattern of $L$. chinensis produced on the automated DNA sequencer (ABI genetic Analyser; 3500xL). Primer 3 was used for amplification reaction.

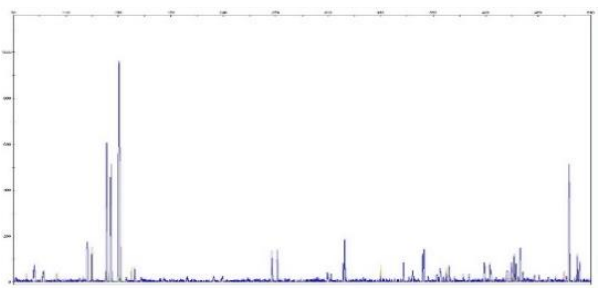

Fig. 11: Fluorogram of RAPD pattern of $M$. brunnae produced on the automated DNA sequencer (ABI genetic Analyser; 3500xL). Primer 3 was used for amplification reaction.

\section{DISCUSSION}

L. chinensis and $M$. brunnae belongs to subfamily Ponerinae and Myrmicinae under the family Formicidae with unique synapomorphies [5] [19]. The present observation with molecular data support monophyly of this family with similarity index 0.6. Both samples formed strong clade with 100 bootstraps. It is suggested that the 32 monomorphic bands generated in both samples may be further used for identifying monophyly of other members of subfamilies.

During the present study Leptogenys chinensis and Myrmicaria brunnae used as representatives of two subfamily Ponerinae and Myrmicinae shown 57.61\% polymorphism provides additional support for branching of poneromorphs from Formicoid [5] [26] with 0.4 genetic distance. 34 polymorphic bands generated i.e. $51.51 \%$ by $L$. chinensis and 53 polymorphic bands i.e. $62.35 \%$ generated by $M$. brunnae could prove to be potential genetic information for identifying differences and similarities among the attribute like genus and within the species using similar RAPD markers.

According to Seppa [22] among well-known ant species only $0.5 \%$ genetic information is available and so using representative species more genetic study should be carried out also added invasive ants are potential threat to the native species and suggested for study of non-neutral genes as many ants have extensive dispersal polymorphism. During the present study more polymorphism was observed with $\mathrm{P} 1$ primer followed by $\mathrm{P} 2$ primer in L. chinensis and M. brunnae, 
could prove to be useful in identifying non-neutral genes in particularly those fragments ranging between 53bp to 326bp.

Anbalagan et al. [2] used RAPD to study genetic diversity within blackfly from different elevation of Palni hills. Hasegawa in 1995 suggested that if RAPD markers are to be used to demonstrate parent-offspring relationship, sperms from queen spermathecal should be incorporated to increase accuracy. Hasan et al. in 2009 [13] studied genetic variability among individuals of $A$. capillaris using ten primers to amplify DNA.

Earlier, RAPD molecular markers were also used to find out genetic relationship among the nests of carpenter ant located in some area by Matta et al. [17] and concluded low genetic differentiation between ant workers from different nests as well as workers within same nests.

Genetic relationship among Lycaenidae butterflies was also carried out using RAPD marker by Tiple et al. in 2009 [24]. Galal (2009) [9] used RAPD and PCR-RFLP markers and concluded that depending upon ease, cost, technical labour, speed and amount of DNA needed, the RAPD marker system should be preferred as they found no difference in RAPD and PCR-RFLP tests. Present study also supports the use of RAPD markers for taxonomic study and polymorphism. During the present study 3 RAPD markers used could be prove helpful for monitoring effects of environmental and chemical changes in soil due to excessive use of manures, fertilizers and other factors ultimately affecting ant's genera. With RAPD's genetic information it will be possible to monitor variation in genes of adopted ant species to changing environment. Monomorphic bands could be further investigated for presence in other related hymenopterans and will help to conclude for their common ancestry.

\section{CONCLUSION}

Dendrogram cluster for $L$. chinensis and M. brunnea shown 2 clusters two samples were linked together with 100bootstrap. L. chinensis and M. brunnea used as representatives of two subfamily Ponerinae and Myrmicinae shown $57.61 \%$ polymorphism and 0.57 genetic variation. The 32 monomorphic bands generated in both L. chinensis and $M$. brunnea by three primers may be further used for identifying monophyly of other members of subfamilies.

\section{ACKNOWLEDGMENT}

We are thankful to CHROMOUS BIOTECH PVT. LTD. for providing RAPD facilities. We are also thankful to Dr. G.B. Ghatalkar for his help.

\section{REFERENCES}

[1] F.W. Allendorf and G. Luikart, Conservation and the genetics of populations. Blackwell Publishing, Oxford, 2007, pp 642.

[2] S. Anbalalgan, C. Bharathiraja, J. Pandiarajan, S. Dinakaran and M. Krishnan, "Use of Random Amplified Polymorphic DNA (RAPD) to study genetic diversity within a population of blackfly, Simulium gravelyi from Palni hills, peninsular India”. Biologia, 67(6),1195-1203 2012.

[3] C. Astruc, J.F. Julien, C. Errard and A. Lenoir, "Phylogeny of ants (Formicidae) based on morphology and DNA sequence data." Molecular Phylogenetics and Evolution, 31,880-893, 2004.
[4] B. Balton, Identification Guide to the Ant Genera of the world. Harvard Univ. Press, Cambridge, MA, 1994.

[5] B. Balton, "Synopsis and classification of Formicidae." Memoirs of the American Entomological Institute, 71,1-370, 2003.

[6] U.C. Baroni, B. Balton and P.S. Ward, "The internal phylogeny of ants (Hymenoptera: Formicidae)", Systematic Entomology, 17,301-329, 1992.

[7] H. Bharti, "Altitudinal diversity of ants in Himalayan regions (Hymenoptera: Formicidae)", Sociobiology, 52,305-322, 2008.

[8] A. Chanda, "A study on ants (Hymenoptera: Formicidae) of Medinipur, West Bengal, India”, International Journal of Entomology Research, 2(5), 1-4, 2017.

[9] F.H. Galal, "Comparison of RAPD and PCR-RFLP markers for classification and taxonomic studies of insects", Egypt. Acad. J. biology. Sci., 2(2),187-195, 2009.

[10] G.B. GATHALKAR AND D.D. BARSAGADE, "Cephalic Microstructure and its role in Predation Biology of Myrmicaria brunnea on Antheraea mylitta", Journal of Applied Biology \& Biotechnology 6(1), 1-6, 2018.

[11] H. Hadrys, M. Balick and B. Shierwater, "Applications of Random Amplified Polymorphic DNA (RAPD) in molecular ecology", Molecular Ecology, 1, 55-63, 1992.

[12] S.M.Z. Hasan, M.S.B. Shafie and R.M. Shah, "Analysis of Random Amplified Polymorphic DNA (RAPD) of Artemisia capillaris (Wormwood capillary) in East Coast of Peninsular Malaysia", World Applied Sciences Journal, 6(7),976-986, 2009.

[13] E. Hasegawa, "Parental analysis using RAPD markers in the ant Colobopsis nipponicus: a test of RAPD markers for estimating reproductive structure within social insect colonies", Ins. Soc., 42, 337$346,1995$.

[14] D.M. Hillis, C. Moritz and B.K. Mable, Molecular Systematics, $2^{\text {nd }}$ Edn. Sinauer Associates, Sunderland. 1996.

[15] B. Holldobler and E.O.Wilson, The Ants. Harvard Univ. Press, Cambridge, MA, 1990

[16] B.R. Mahalakshmi and H. Channaveerappa, "Diversity of ant species (hymenoptera: formicidae) in the campus of maharani's science college for women: a mini model of habitat persistence", International Journal of Pure and Applied Zoology, 4 (3),277-281, 2016.

[17] S.L.S.F. Matta, M.S.C. Morini and A.W.S. Hilsdorf, "Genetic relationship among Camponotus rufipes Fabricius (Hymenoptera: Formicidae) nests by RAPD molecular markers", Acta Scientiarum, Biological Science, 35(1),89-92, 2013.

[18] R. Ojha, S.K. Jalali, T.M.M. Ali, T. Venkateshan, S.W. Prosser and N.K. Krishnakumar, "DNA barcoding of Indian ant species based on cox1 gene", Indian Journal of Biotechnology, 13,165-171, 2014.

[19] G.D. Ouellette, B.L. Fisher and D.J. Girman, "Molecular systematics of basal subfamilies of ants using 28S rRNA (Hyemnoptera: Formicidae)", Molecular Phylogenetics and Evolution, 40,359-369, 2006.

[20] E. Rocin and L. Deharveng, "Leptogenys khammouanensis sp. Nov. (Hymenoptera: Formicidae). A possible Troglobitic Species of Laos, with a Discussion on cave Ants", Zoological Science, 20, 919-924, 2003.

[21] C. Saux, B.L. Fisher and G.S. Spicer, "Dracula ant phylogeny as inferred by nuclear $28 \mathrm{~S}$ rDNA sequence and implications for ant systematics (Hymenoptera: Formicidae)", Molecular Phylogenetics and Evolution, 33,457-468, 2004.

[22] P. Seppa, "Do ants (Hymenoptera: Formicidae) need conservation and does ant conservation need genetics?" Myrmecological News, 11,161$172,2008$.

[23] P. Skroch, J. Tivang and J. Nienhuis, "Analysis of genetic relations using RAPD marker data" In: Proceeding Joint plant Breeding Symposia Series, Minneapolis. Crop Science Society of America, American Society for Horticultural Science, American Genetic Association, Minneapolis.pp26-30, 1992.

[24] A.D. Tiple, A.M. Khurad and S.V. Padwad, "Genetic relationship among some Lycaenidae butterflies as revealed by RAPD analysis", Cytologia, 74(2), 165-169, 2009.

[25] A.M. Waldschmidt, P. Marco-junior, E.G. Barros and L.A.O. Campos, "Genetic analysis of Melipona quadrifasciata Lep. (Hymenoptera: Apidae, Meliponinae) with RAPD markers". Brazilian Journal of Biology, 62(4B),923-928, 2002.

[26] P.S. Ward, "Adetomyrma, an enigmatic new ant genus from Madagascar (Hymenoptera: Formicidae), and its implications for ant phylogeny". Systematic Entomology, 19,159-175, 1994. 
European Journal of Biology and Biotechnology

www.ejbio.org

[27] P.S. Ward and S.G. Brady, "Phylogeny and biogeography of the ant subfamily Myrmiciinae (Hymenoptera: Formicidae)", Invert. Syst., 17,361-368, 2003.

[28] P.S. Ward, S.G. Brady, B.L. Fisher and T.R. Schultz, "Assembling the ant "Tree of Life" (Hymenoptera: Formicidae)", Myrmecologische Nachrichten, 7,87-90, 2005.

[29] E.O. Wilson, Success and dominance in ecosystems: the case of social insects. Ecology Institute, Oldendorf/Luhe, 1990, pp105. 